\title{
FROM PAST TILL PRESENCE - THE QUALITY OF GERMAN PHYSICAL ACTIVITY KINDERGARTEN (PAK)
}

\author{
Rolf Schwarz \\ Department of Physical Education, Motor Development \& Diagnostics, Institute of Physical Education \& Sport. \\ Pädagogische Hochschule Karlsruhe

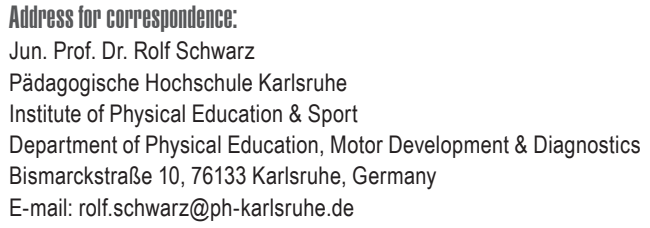

\begin{abstract}
Ahstract. Physical Activity Education (PAE) has always been playing an important role in the history of Early Childhood Education (ECE) in Germany and its institutionalized form called "Kindergarten". As a key feature of Kindergarten quality Physical Activity (PA) was originally considered to be either a compensation for children's health dangers along with the neglect by their hard working mothers or a mere medium for other developmental fields such as cognition or social behavior. The subjectively observed outcome for the pedagogues was far from empirically objective evidence. Till the 1970s neither the technical term "quality" nor any empirical quality standards existed in German ECE to assess the effect of PA in Kindergarten. This fairly hasn't changed yet although some general findings of high quality effects can be reported as well as PA specific results from a recent review on systematic PAE programmes. Despite this fact, Germany's organized sports associations (OSA) installed 1759 Physical Activity Kindergarten (PAK) with great expectations in their overall positive developmental effect. For quality assurance some criteria were developed to achieve a minimum standard level. Subsequently a very popular license originated without having evidence for its positive outcome. A randomized, controlled longitudinal study is still to come.
\end{abstract}

Key World: physical activity kindergarten, quality, early childhood education

\section{Introduction}

What makes a good or even ideal Kindergarten? And what role does Physical Activity (PA) as an educational and health dimension play in this question? As long as the researcher's notion doesn't only refer to a single institution of Early Childhood Education (ECE) but to the Kindergarten as such, probably the most elaborated answer given in Germany lies in the model of Tietze and Viernickel (2007). Not less than 1783 quality criteria, divided up into 21 quality dimensions and six transversal pedagogic principles claim "best practice" (dito, p. 27). The sheer amount of criteria derives from a nationwide quality initiative (NQI) by the Federal Ministry of Family, Elderly People, Women 
and Youth (BMFSFJ) aiming at a consensual framework between scientists, politicians and the municipal quality managers for what the overall quality is made of in German Kindergarten (see Table 1).

Table 1. The 1.783 quality criteria divided up into 21 dimensions and 6 transversal pedagogical principles of German high Kindergarten quality according to the NQI by Tietze and Viernickel (2007)

\begin{tabular}{|c|c|c|c|c|c|c|c|c|c|c|c|c|c|c|c|c|c|c|c|c|c|c|c|}
\hline \multirow{2}{*}{$\begin{array}{c}6 \text { transversal } \\
\text { principles }\end{array}$} & \multicolumn{23}{|c|}{21 quality dimensions } \\
\hline & 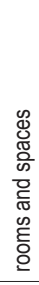 & 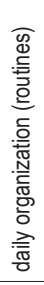 & 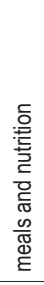 & 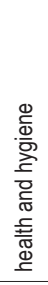 & 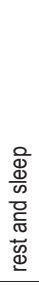 & 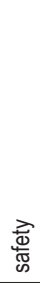 & 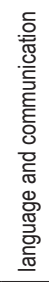 & 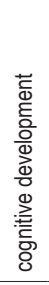 & 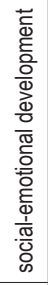 & 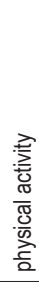 & 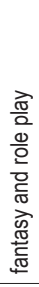 & 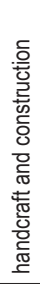 & 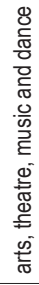 & 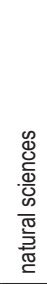 & 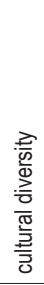 & 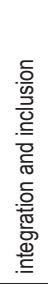 & 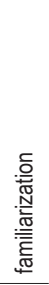 & 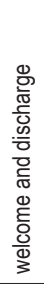 & 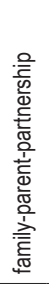 & 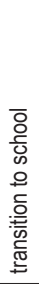 & 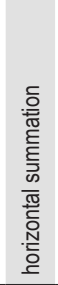 & 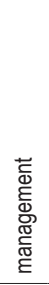 & $\begin{array}{l}\text { The } 8 \text { specific } \\
\text { management } \\
\text { quality criteria }\end{array}$ \\
\hline $\begin{array}{l}\text { Rooms } \\
\text { and spatial } \\
\text { framework }\end{array}$ & 18 & 1 & 14 & 21 & 9 & 12 & 9 & 13 & 9 & 15 & 5 & 10 & 10 & 10 & 8 & 9 & 5 & 4 & 8 & 3 & 193 & 19 & leadership \\
\hline $\begin{array}{l}\text { Teacher-child- } \\
\text {-interaction }\end{array}$ & 10 & 20 & 18 & 16 & 12 & 15 & 54 & 36 & 59 & 17 & 16 & 12 & 21 & 18 & 32 & 11 & 23 & 7 & 24 & 19 & 440 & 57 & $\begin{array}{l}\text { organization of } \\
\text { daily work (time } \\
\text { management) }\end{array}$ \\
\hline Planning & 14 & 29 & 27 & 47 & 20 & 31 & 26 & 50 & 39 & 12 & 13 & 15 & 19 & 24 & 50 & 24 & 21 & 13 & 8 & 27 & 509 & 34 & $\begin{array}{c}\text { human } \\
\text { resources } \\
\text { and personell } \\
\text { management }\end{array}$ \\
\hline $\begin{array}{l}\text { Diversity } \\
\text { and usage } \\
\text { of material }\end{array}$ & 7 & 0 & 6 & 7 & 4 & 6 & 9 & 26 & 9 & 10 & 4 & 8 & 12 & 10 & 6 & 2 & 0 & 1 & 0 & 2 & 129 & 18 & $\begin{array}{c}\text { conceptual } \\
\text { development }\end{array}$ \\
\hline Individualization & 4 & 7 & 4 & 6 & 7 & 3 & 9 & 8 & 22 & 5 & 3 & 6 & 5 & 6 & 15 & 6 & 6 & 6 & 10 & 6 & 144 & 12 & $\begin{array}{l}\text { public relation } \\
\text { and networking }\end{array}$ \\
\hline Participation & 21 & 11 & 14 & 7 & 9 & 6 & 13 & 15 & 15 & 10 & 10 & 12 & 8 & 17 & 7 & 7 & 2 & 3 & 10 & 7 & 204 & 5 & $\begin{array}{c}\text { political } \\
\text { engagement }\end{array}$ \\
\hline $\begin{array}{l}\text { Vertical } \\
\text { summation }\end{array}$ & 74 & 68 & 83 & 104 & 61 & 73 & 120 & 148 & 153 & 69 & 51 & 63 & 75 & 85 & 118 & 59 & 57 & 34 & 60 & 64 & 1619 & 11 & $\begin{array}{c}\text { quality } \\
\text { control and } \\
\text { development }\end{array}$ \\
\hline & & & & & & & & & & & & & & & & & & & & & $\downarrow$ & 8 & finance \\
\hline & & & & & & & & & & & & & & & & & & & & & plus: & 164 & $\begin{array}{c}\rightarrow \text { Total } \\
\text { of } 1.783 \\
\text { quality criteria }\end{array}$ \\
\hline
\end{tabular}

With a closer look from the Physical Activity Kindergarten (PAK) perspective it is crucial to know why there should be exactly 69 quality criteria and not 120 or just 5 . The simple answer is: We just don't know, because all of the 69 criteria haven't been confirmed yet in a study design that takes the developmental outcome of children by a randomized, controlled and longitudinal empirical framework into concern. Therefore, to understand why these specific quality features might be the right ones, two ways of explanation ought to be followed: first, one throws a glance at the historical roots of PAK in Germany to deduce the consolidated experience and the knowledge of best practice throughout the last 250 years. Second, one collects all data existing in general about high quality programs designed for ECE-Physical Activity interventions in Germany. Both ways will be shown in the following. 


\section{Historical Roots}

Worldwide the German pedagogue Friedrich Wilhelm August Fröbel (1782-1852) is supposed to be the inventor of the Kindergarten as the earliest type of institutional education in child development. In fact, this is a downright error in many of the literature about the history of German Kindergarten (Aden-Grossmann 2011; Konrad 2012). It was Johann Friedrich Oberlin (1740-1826) instead, a German cleric and pedagogue, who adopted the already existing idea of the Alsace-Lorraine Sara Banzet to give very young, hungry and neglected children a shelter (Burckhardt 1843a; Psczolla 1979). These snuggeries where gradually combined with more ambitious care in terms of reasonable activity and education, e.g. learning a foreign language (French), reading and writing, natural sciences and knitting. The latter is the reason why they were called "Strickstuben" (French: "poeles à tricoter") or "knitting snuggeries". Furthermore, Oberlin attached great importance to PA by playing physical games. On the one hand his aim was to strengthen the children's organism and health, on the other to improve social behaviour by PA (Pelser 2002). Altogether this very early form of Kindergarten already included the most important so called developmental areas or educational fields of modern German ECE-curriculums such as language, nature, cognition, body and health, motor and social development and ethical/religious questions (MKJS 2011; BSASFF 2012).

Beside this public-clerical approach supporting ECE, the private-economic engagement of Robert Owen (1771-1858) heavily influenced an additional type of German Kindergarten, so called "Betriebskindergarten" or "company-run childcare/daycare facility" (Höltershinken 2003). Established in 1816 at the Scottish New Lanark during the Industrialization, his "Infant Schools" should relieve the hard working mothers from nursing their children, giving the former the opportunity to attend regular work throughout the day and the latter ones to read, write, knit and play physical games especially outdoors in light and fresh air (Owen 1841). Similar to Oberlin's Strickstuben the Infant Schools not only took the important role of PA for the overall development of children into account but also Kindergarten as the fundament of a new, meaning better society (Owen 1813; Owen 1840).

Almost 50 Years later a second important historical step was taken with the "Kinderbewahranstalten". These daycare centres were ECE-facilities for all children in the rapidly growing cities, were poverty, disease, crime and neglect were widespread. In terms of education, it is reported that there was (a) a sheer non-education by the mothers due to absence, going to work, (b) a bad education by surrogate mothers, neighbours or others, (c) a bad education by the mother herself as she had no time or expertise nor patience (Chimani 1832; Bönig 2012). At that time the concept by Johann Georg Wirth (1807-1851) on the one hand focused on the unpretentious care of the neglected children. On the other hand Kinderbewahranstalten not only supported the mothers and families by setting the parents free for work but to teach the 2-6-year-old in handcraft, singing, praying and religion, memory tasks, writing, reading, speaking clearly, arithmetic and: physical activity. Again, beside nutrition and clothing PA was considered to be the most important tool for generating health and a strong organism in ECE. Furthermore, cognitive stimulation and the training of social behaviour were serious goals of this type of Kindergarten. The PA-curriculum consisted of stretching, walking (sometimes military marching), running, jumping and bouncing around. Wirth especially accentuated the social, motor and health profits of playing outdoors on the facility's own playground. Some years later the "Kleinkindschulen", e.g. by Johannes Fölsing (1816-1882), were based on the same previous content but with a new emphasis highlighting the preparation for real school by extending and deepening learning exercise. That comprised a disciplined type of learning and more earnest, functionalized play. This type of Kindergarten, more school than an appropriate ECE-centre, used PA ("Leibeserziehung") as a compensation for the more intellectual and cognitive challenging instruction based learning (Fölsing 1846, 1848). In the course of this major milestone 
along the historical pathway of German Kindergarten Friedrich Wilhelm August Fröbel (1782-1852) introduced the technical term "Kindergarten" in the context of a institutionalized setting of ECE:

Human as a child, like a flower, a blossom on a tree: that's how children relate to human mankind, a recurrent appearance of a new mankind (1874: 470).

In the line of other pedagogical reformers Fröbel defined Kindergarten as the breeding ground of a new and better society. And nothing less but the specific goals, content and methods of this Kindergarten was the conceptual framework of the socially redesign on a nationwide scale. Interestingly enough play, the right play material ("Spielgaben") and physical activity was supposed to be a major fundamental educational tool therein.

To draw a first conclusion of this historical root, the answer to the opening question what a very good Kindergarten is made of, can be easily given for the 18th and middle of the 19th century: First, much is about the satisfaction of basic needs of children, wherein PA plays a dominant role. Second, high quality is derived from the success Kindergarten can prepare children for the requirements of the subsequent learning school. Still the quality discussion of that time stays at a very early stage of whether or not some of the little amount of quality criteria is existent on a nominal or ordinal scale at maximum (yes vs. no, more vs. less). Giving consideration to the objective empirical effects of a distinguished pedagogical measure, method, process or arrangement the standard of discussion remained on a very low scale at that time.

This changed when the Prussian government took over the educational system between around 1850 till 1918. They realized that the main idea of forming a new society by institutionalized ECE was somehow dangerous for their own political enterprise (Nacke 1853; Stiehl 1858). Concurrently or just because of this the Prussian government tried to use the recognizable if not measurable effects of Kindergarten themselves. The children were trained with high discipline for new goals e.g. strong patriotism, loyalty to the German emperor and preparation for future wars. Practically the boys were motivated by playing war games (Figure 1) and exercising in marching and troop games (Figure 2), building trenches in the sandpit or tinkering military equipment. High PA-quality in Kindergarten was then derived from the success the education prepared well for serving the Prussian government.

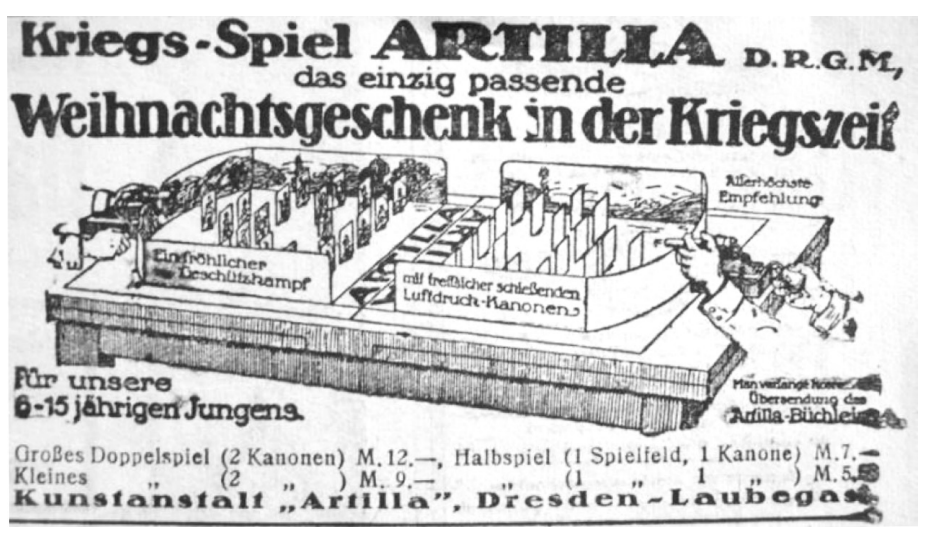

Figure 1. War game "Artilla" as a means of hand motor education for boys - Academy of Arts Dresden, picture print of the original advert in 1916. By courtesy of Karl-Heinz Stamm, Glauchau 


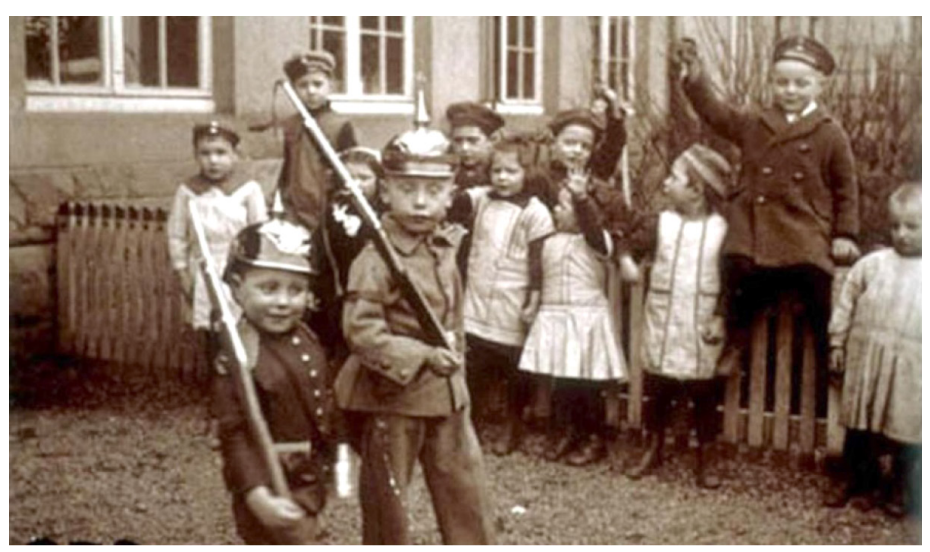

Figure 2. "Marching of the troops". Physical activity education as a marching game in a Munich Kindergarten in 1914. By courtesy of Dr. Günter Erning, picture archive Bamberg

Gradually new pedagogical ideas tried to resist the educational suppression by reinventing the perspective on childhood as such. Initiated by a former Kindergarten teacher of Fröbel, Henriette Schrader-Breymann (18271899), quality in Kindergarten was less measured according to neither the preparation success for school nor the repression of developmental fields in order to form dutiful soldiers (1894/1962). Instead, by the end of the 19th century, the so called "Reformpädagogik" (Engl.: "reformist pedagogy" or "progressive education") gave back the principles of individualization, total developmental support for children, co-operative relationship with the teacher, self-determined leisure time activities and the experience of nature and freedom. Especially Maria Montessori (1870-1952) heavily influenced the ECE-system with a new picture portraying children being active, creative, constructive and competent draftsmen of themselves (Ital.: "construttore") (Montessori 1965, 1972). The German "Montessori-Kindergarten" in 1919 by Clara Grunwald (1877-1943) was consequently designed as a virtual PA-Kindergarten, where children learned and grew up locomotively autonomous and self-reliant using specially designed materials and learning environments (Grunwald 1920, 1995). So far, physical education has never been so important.

Ironically, the predominant role of PA in ECE not only persisted till 1933, when Reformpädagogik ideas were displaced by National Socialismus. On the contrary, the Nazis even strengthened PA education (PAE) to the utmost conceivable state. The leading ECE principles of this new "Leibeserziehung" then were: selection of the strongest children to further support them and filtering the weak ones, body hygiene and racial health, discipline and absolute obedience to the "Führer" and the willingness to sacrifice oneself for one's own country (Rauschning 1940; Vorländer 1988). These political goals were transformed into concrete exercises and PA-units as there were athletics with running, throwing (as a preparation for using the hand grenade) and jumping, outdoor gymnastics (fresh air and light hypothesis; Benzing 1942) or competition games with winners and losers in terms of the selection quality feature (Ivers 1935). For the first time, the quality outcome and effects of PAE-efforts were empirically measured e.g. with motor diagnostic in athletics. In addition, three scientific institutes were founded to explore the deeper origin of race psychology and development to give the Kindergarten teachers precise information about how 
to execute high quality PA-didactics (PAD) in terms of National Socialism ideology. Overall, PAE was the key to a total quality management in ECE with a new Aryan race as the target group.

After the Second World War the ECE-system was completely devastated. The need for a reliable, innocuous PAD led the pedagogues back to the ideas of the Reformpädagogik, were PA was the fundament of physically exploring nature and culture. The facilities were still called Kindergarten and were again given a strong part in the educational system of the new Federal Republic of Germany (western part) by law. Even more, in the 1970s the powerful German Education Council officially referred to the term "quality" for the very first time by using scientifically generated data on an empirical-objective basis. In the course of this scientifically grounded ECE the introduction of what we currently know the "Bewegungskindergarten" or Physical Activity Kindergarten (PAK) took place.

The first type of PAK called "Sportkindergarten" was founded in 1972 at Freiburg i.Br. by a local gymnastics club (Zimmer 1993; Schaffner, 2005). The quintessence of modern PAK in contrast to the mere additive way of using PA as an educational medium was to define PA as the inner core of the pedagogic concept of an ECE-facility. However, this integrated and transversal strategy at that time was designed to prepare mainly for the sports culture, meaning a strong focus on training principles and motor skill acquisition rather than a broad and self-directed experience of whatever learning situation in a variable motor developmental perspective. The first aspect mentioned became known as the education for sport in the sense of simply teaching an already existing sport culture with its corresponding techniques. The second aspect, education through sport/physical activity, underlined the wide range of motor situations not necessarily dependent on cultural guidelines. It refers to a free and open motor development using human motor behavior not only as a means of transporting other developmental fields such as cognition, language, social behavior or health - just as Oberlin did 200 years ago (Prohl 1999). But also as a means for itself, meaning PA without any deeper pedagogical requirements but just for fun and as a human basic need. Especially Zimmer appears to be a prominent pioneer of this new scientific understanding of sport pedagogy in Kindergarten called "Bewegungserziehung" $(1993,2006)$ which is currently pursued by Schwarz (2014a) on an even more empirical basis. Today we exactly find 1759 PAKs in Germany, licensed by the specific OSA of each federal state in Germany of which 16 exist (status: 31.12.2014, Schwarz 2015). That's 3.25\% of all ECE-facilities (Destatis 2014) with a monthly growth rate of 17 PAKs all over Germany. The crucial question within the current quality debate is whether these modern PAKs can really keep the promise they pretend, due to an overall positive effect on relevant developmental fields.

\section{General and specific empirical evidence}

Until now not a single empirical study on a reliable, objective or valid level has been published in Germany to examine the sustainable effects of a modern OSA-licensed PAK on distinguished developmental fields except one to come (Schwarz 2015, in prep.). The only thing we know is a collection of all the quality criteria PAKs consist of, five to eleven in number: (1) co-operation with sports clubs or other health and sports related institutions, (2) a high qualification of the PE Kindergarten teachers in special courses, (3) a designated pedagogical concept with PA and motor development at its heart, (4) offering an appropriate time to move and being physically active indoors and outdoors, (5) special activity rooms ("Bewegungsräume") both indoors and outdoors, (6) the right material, (7) family partnership (work and act together with the parents), (8) public relations and networking, (9) documentation of all quality measures, (10) mobility of parents bringing their children to Kindergarten and finally (11) the motor safety of 
the facility. But can a maximum amount of eleven criteria encompass the entire PA-quality of a complex ECE-centre, even more if the general NQI suggests 69 features? Apart from empirical evidence this rhetorical question can be critically answered by a simple theoretical argumentation. Taking the feature number five "special activity rooms" into account very often the PAK concepts speak of "enough", "appropriate", "stimulating" or "childlike" space. Still, when is "enough" enough? The only satisfactory answer obviously is a quantitative one, because it helps to precisely differ a good from a bad activity space. No one can say - using for example a binary logistic regression - whether the Odds Ratio (OR) of more or less $10 \mathrm{~m}^{2}$ outdoor space makes the significant difference with a high power in a certain dimension of developmental promotion. Thus even the little amount of motor quality criteria of PAKs tends to have weaknesses in its construction of validity within as they lack of accurate cutoffs. Furthermore, the PAK criteria are predominantly of a structural character neglecting the vital processes. As the pioneer of defining "quality" as such in the medical and health area, Avedis Donabedian $(1966,1980)$, differentiates between three quality dimensions, namely structure (a. input, b. organization), process (a. content, b. configuration) and outcome (a. end point, b. impact) it is quite obvious, that most of the PAK criteria can be placed singularly in the structural dimension. Table 2 shows the transformation of the Donabedian model on an ECE-facility in general and PAKs specifically.

Table 2. Fundamental model of quality dimensions transferred to ECE facilities and PAKs according to Donabedian $(1966,1980)$

\begin{tabular}{|c|c|c|}
\hline $\begin{array}{l}\text { Structure: } \\
\text { a. Inputs, b. Organization }\end{array}$ & $\begin{array}{c}\text { Process: } \\
\text { a. Content, b. Configuration }\end{array}$ & $\begin{array}{c}\text { Outcome: } \\
\text { a. End Point, b. Impact }\end{array}$ \\
\hline $\begin{array}{l}\text { Examples in PAK: } \\
\text { - Size of facility }\left(\mathrm{m}^{2}\right) \\
\text { - teacher-children-ratio } \\
\text { - Size of children groups (units) } \\
\text { - Grade of staff qualification } \\
\text { - Type of working material and toys } \\
\text { - Network and co-operation agreement and treaties } \\
\text { - Safety requirements and hygiene } \\
\text { - Education curriculum and concept } \\
\text { - Number and content of further job training }\end{array}$ & $\begin{array}{l}\text { Basic meaning: } \\
\text { Total of all observable activities and services } \\
\text { that produce an outcome in type and number } \\
\text { Examples in PAK: } \\
\text { - Familiarization and admission of children } \\
\text { - Interaction with children (e.g. responsivity) } \\
\text { - Direct co-operation with parents } \\
\text { - Involvement of parents into the day-care and } \\
\text { total quality management (e.g. workshops } \\
\text { conducted by parents) } \\
\text { - Interaction between day-care manager } \\
\text { and municipality } \\
\text { - Visibility of content, goals and results of the } \\
\text { everyday work (e.g. pictures pinned on the } \\
\text { information board, data documentation, etc.) } \\
\text { - Means of scaffolding e.g. in the gymnasium }\end{array}$ & $\begin{array}{l}\text { Basic meaning: } \\
\text { The observable results and effects } \\
\text { on the target group that evidently } \\
\text { can be derived from the overall input } \\
\text { (input-outcome-difference) } \\
\text { Examples in PAK: } \\
\text { - Well-being of children } \\
\text { - Satisfaction of parents } \\
\text { - Developmental progress of the children } \\
\text { in the educational fields of cognition, } \\
\text { language, body and health, physical } \\
\text { activity, sensual development, social } \\
\text { behaviour, religion, etc. } \\
\text { - Prosperity of society (overall effects } \\
\text { of ECE on later outcomes e.g. higher } \\
\text { net-incomes, lower crime rate, etc.) }\end{array}$ \\
\hline
\end{tabular}

Tietze (1998) and Tietze et al. (2005) examined the influence of the structural and the process dimensions on the outcome as measured by the developmental progress in selected fields of ECE. Accordingly it seems evident that

- the structural input considerably influences the pedagogical process quality $\left(R^{2}=0.48^{\star * *}\right.$; blockwisehierarchical regression) i.e. nearly half of the statistical differences correlating to process quality may be explained by variables of structural quality. That especially applies for the job experience of Kindergarten teachers, the teacher-children-relation (e.g. $1: 8)$, the duration of opening hours and the space offered $\left(\mathrm{m}^{2}\right)$. 
- Second, the quality of pedagogical processes preferentially in families and subordinately in ECE-facilities significantly correlate with the social $\left(R^{2} \approx 0.20^{*}\right)$, linguistic $\left(R^{2} \approx 0.32^{*}\right)$ and the outcome of life competence $\left(R^{2} \approx 0.31^{*}\right)$.

Dohmen (2005) summarizes the empirical effects of structural and process quality on the outcome with respect to their sustainability in general (Table 3).

Table 3. Short-, medium- and long-term effects of a better structural and process quality on the children's outcome (developmental fields)

\begin{tabular}{lll}
\hline \multicolumn{1}{c}{ Short-term } & \multicolumn{1}{c}{ Medium-term } & \multicolumn{1}{c}{ Long-term } \\
\hline - higher IQ & - earlier school enrolment & - derive one's income earlier \\
- more pro-social behaviour & - leaving school earlier & - higher net-income \\
- better nutrition & - higher probability of attending higher & - lower risk of unemployment \\
- better overall health and well-being & education e.g. university & - higher job productivity \\
- higher self-esteem & - more pro-social behaviour & - lower crime rate, more pro-social \\
- improved parent-child-interaction & & behaviour \\
- higher self-contentment & & \\
\hline
\end{tabular}

Schwarz (2014b) collects all data existing in particular about high quality programs designed for ECEPhysical Activity interventions in Germany. This latest review comprises all systematically, controlled longitudinal studies ever conducted in Germany from 1980-2013 examining effects on children's outcome (motor development, cognition, social-emotional development and physical health). Other inclusion criteria were duration of intervention ( $\geq 6$ months), a minimum of two measure points, age between three and eight years, at least two dependent variables (motor development plus $\mathrm{x}$ ) and a sample size of $\mathrm{N} \geq 25$. The result: 14 studies comply with the methodical requirements (Table 4).

Table 4. Review of controlled longitudinal studies in Germany (1980-2013) on the effects of systematically designed PA intervention programmes in ECE-facilities, $\mathrm{N}=14$

\begin{tabular}{|c|c|}
\hline Target variable & Outcome - Effects on dependant variables \\
\hline Motor development & $\begin{array}{l}\text { PA intervention programmes (Motor behaviour as influencing variable) have a positive effect almost every time they are applied } \\
\text { on motor development. Ten out of } 14 \text { studies show significant results. Main outcome: the weaker the children (retarded), the } \\
\text { earlier they get more physically active (very early PAE) and the more often they get intervened (daily intervention) the stronger } \\
\text { the effects (max. } \eta^{2}=0.33 \text {; MANOVA over time). }\end{array}$ \\
\hline Cognition & $\begin{array}{l}\text { Six studies deliver findings on cognition, mainly dealing with } I Q \text {-tests, sometimes concentration and very rarely to memory. } \\
\text { Correlations range from } 0.22^{* *} \text { to } 0.40^{* * *} \text { at the } I Q \text { and between } 0.31^{* *} \text { to } 0.46^{* * *} \text { at the concentration findings. Memory results } \\
\text { are very heterogeneous. }\end{array}$ \\
\hline $\begin{array}{l}\text { Social-emotional } \\
\text { development }\end{array}$ & $\begin{array}{l}\text { Inconsistent findings: very positive results face totally absent effects on the contrary. This can be explained by a different } \\
\text { understanding of how to define social-emotional development. There is not a single study using interference statistics. }\end{array}$ \\
\hline Physical health & $\begin{array}{l}\text { Studies }(N=6) \text { on this target variable are mainly of medical and public health character. The findings show low blood pressure } \\
(p<0.001) \text {, increase of abdominal muscle strength }(a=0.002) \text {, decrease of subcutaneous adipose tissue }(p=0.13) \text {, deeper } \\
\text { and more regular sleep. There are no psychosomatic effects examined at all in the long run. }\end{array}$ \\
\hline
\end{tabular}


From a qualitative perspective these systematic PA interventions may be of some reasonable effect on the outcome. But concerning the structural or process input there are only confuse notions about what really works. These imprecise intervention variables are (1) intensive qualification of Kindergarten teachers, (2) variable application of material and PA toys, (3) motivating (childlike) PA content, (4) better timing of PA units and didactically structuring them, (5) integration of the parents as a role model (PA at home), (6) re-designing of rooms indoor and outdoor (more space) and finally (7) using a handbook of documentation and manual of reliable quality standards. However, there is little known about the exact empirical effects of these rather 'variables of tendency'.

Therefore, the author is in the line with the theoretical claims of Leu (2005) and Tietze and Förster (2005) that licensed Kindergartens should fulfill several meta-requirements. Without them, a further, mere quantitative expansion of OSA-licensed PAKs would be at least questionable:

- A consensual quality definition has to be found. Only if there is a mutual understanding the generalization of appropriate criteria is successful.

- This general validity implies an intensified empirical objective research, separating the sheep from the goats.

- To do this one clearly needs operationalized and therefore measurable indicators for the quality standards to describe, analyze and interpret Kindergarten quality.

- Such sort of evaluation is not for laypersons but for experts and scientific staff, meaning that a high quality certification, like the announced PAKs, needs high quality evaluators that ought to be neutral.

\section{Conclusion}

Since the installation of Kindergarten in Germany PAE has always been playing a vital role in the ECE-curriculums. On a very plain level it seemed subjectively obvious for former pedagogues that motor intervention is a fundamental key to satisfy basic needs of children. The main function of PAE till the middle of the 19th century was compensating the health dangers in the wake of growing cities or the neglect by the working mothers. A high quality Kindergarten in this sense helped to keep children alive and somehow engaged. Later on PAE became a medium of preparation for school and forming the children as a good serving member for society and soldiers at war times. High quality in Kindergarten saved the outcome as a somehow 'social investment'. It wasn't until the end of the 19th century when a new perspective arouse wherein children were considered to be active and creative by nature with fundamental rights for autonomy and self-determination. Forty years after the Second World War this attitude became the leading principle not only in ECE in general but also in PAE.

The "Bewegungskindergarten" (PAK) of Germany's organized sports associations (OSA) picked up the traditionally high expectations considering the effects of PAE and installed a minimum quality management by designing some criteria as a matter of quality assurance. However, only some general findings of high quality effects can be reported as well as PA specific results from a recent review on systematically designed PAE programmes. Despite this fact, Germany's OSA are still expanding Physical Activity Kindergarten (PAK) believing in their overall positive developmental effect. Subsequently a very popular license originated without having evidence for its positive outcome. A randomized, controlled longitudinal study is still to come. 


\section{References}

Aden-Grossmann W. Der Kindergarten: Geschichte - Entwicklung - Konzepte. Beltz, Weinheim 2011.

Benzing R. Grundlagen der körperlichen und geistigen Erziehung des Kleinkindes im nationalsozialistischen Kindergarten. Zentralverlag der NSDAP. Berlin 1942.

Bönig J. Zur Geschichte der Kinderarbeit. APuZ. 2012; 62 (43): 3-9.

BSASFF - Bayerisches Staatsministerium für Arbeit und Sozialordnung, Familie und Frauen. Der Bayerische Bildungs- und Erziehungsplan für Kinder in Tageseinrichtungen bis zur Einschulung. Cornelsen. Berlin 2012.

Burckhardt W. Johann Friedrich Oberlin's vollständige Lebensgeschichte und gesammelte Schriften. Scheible, Rieger \& Sattler. Stuttgart 1843.

Chimani L. Theoretisch-practischer Leitfaden für Lehrer und Kinder-Bewahranstalten. Enthaltend die Organisation derselben und die Gegenstände, welche und wie sie in denselben vorgenommen werden sollen. Pichler. Wien 1832.

Destatis. Statistik der Kinder- und Jugendhilfe. Kinder und tätige Personen in Tageseinrichtungen und in öffentlich geförderter Kindertagespflege. www.destatis.de/DE/Publikationen/Thematisch/Soziales/KinderJugendhilfe/TageseinrichtungenKindertage spflege.html (1.03.2014).

Dohmen D. Kosten und Nutzen eines Gütesiegels im Kita-Bereich. In: Der Streit ums Gütesiegel. Qualitätskonzepte für Kindertageseinrichtungen, eds. A. Diller, H.R. Leu, Th. Rauschenbach. Verlag Deutsches Jugendinstitut. München 2005: $67-108$.

Donabedian A. Evaluating the Quality of Medical Care. Milbank Memorial Fund Quarterly. 1966; 44 (3): 166-203.

Donabedian A. Explorations in Quality Assessment and Monitoring. The Definition of Quality and Approaches to its Assessment (Vol. 1). Health Administration Press. Michigan 1980.

Fölsing J. Erziehungsstoffe oder Beiträge zu einer erfolgreichen Erziehung der zarten Kindheit in leichten Gesängen, Spielen, Körperübungen, Gebeten - für Familien und Kleinkinderanstalten. Leske. Darmstadt 1846.

Fölsing J. Die Kleinkinderschulen, wie sie sind und was sie sein sollen. Material zum Fundament beim neuen Aufbau des dt. Volksschulwesens. Gotth. Wilh. Körner. Erfurt 1848.

Grunwald C. Über die Methode der wissenschaftlichen Pädagogik der Ärztin und Psychologin Dr. Maria Montessori. Die Neue Erziehung. 1920; 10: 421-426.

Grunwald C. Das Kind ist der Mittelpunkt. Kinders Verlag. Ulm 1995.

Höltershinken D. Von den ersten Kleinkinderschulen, Bewahranstalten und Kindergärten bis zum Rechtsanspruch auf einen Kindergartenplatz. Beiträge zur Geschichte der Dortmunder Kindergärten. Projektverlag. Bochum 2003.

Ivers H. Lustige Kampf- und Ulk-Bewegungsspiele. Für überall in Turnhalle, Tanzsaal, Zimmer, Kabarettbühne, Zirkusmanege, im Freien auf Spielplätzen, in Wald und Heide und im Wasser. Danner, Mühlhausen i. Thür. 1935

Konrad F.-M. Der Kindergarten. Seine Geschichte von den Anfängen bis in die Gegenwart (2nd ed). Lambertus. Freiburg i.Br. 2012.

Leu H.R. Kontroverse Perspektiven auf die Festlegung von Qualitätskriterien. In: Der Streit ums Gütesiegel. Qualitätskonzepte für Kindertageseinrichtungen, eds. A. Diller, H.R. Leu, Th. Rauschenbach. Verlag Deutsches Jugendinstitut. München 2005: 13-30

MKJS - Ministerium für Kultur, Jugend und Sport Baden-Württemberg. Orientierungsplan für Bildung und Erziehung in badenwürttembergischen Kindergärten und weiteren Kindertageseinrichtungen. Herder. Freiburg i.Br. 2011.

Montessori M. Grundlagen meiner Pädagogik. Quelle \& Meyer. Heidelberg 1965.

Montessori M. Das kreative Kind. Der absorbierende Geist (7th. ed). Herder. Freiburg i.Br. 1972.

Nacke C. Pädagogischer Jahresbericht für Deutschlands Volksschullehrer. Kessinger Legacy Reprints Pub. Co. Montana 1853.

Owen R. A new view of society. Cadell \& Davies. London 1813.

Owen R. Essays on the formation of the Human Character B.D. Cousins. London 1840.

Owen R. Address of opening the Institution for the Formation of Character at New Lanark. Home Colonization Society. London 1841.

Pelser H.O. Johann Friedrich Oberlin. Seelsorger, Sozialreformer und Pädagoge. Clio-Verlag. Konstanz 2002.

Prohl R. Grundriss der Sportpädagogik. Limpert. Wiebelsheim 1999.

Psczolla E. Johann Friedrich Oberlin. Verlagshaus Gern Mohn. Gütersloh 1979.

Rauschning H. Gespräche mit Hitler. Europa Verlag. Zürich 1940. 
SchaffnerK. Sport-und Bewegungskindergärten: pädagogisches Konzept. In: LSB Hessen-Landesssportbund (eds). Zukunftsorientierte Sportstättenentwicklung. Sport- und Bewegungskindergärten: Grundlagen - Konzepte - Beispiele. Landessportbund Hessen e.V. Frankfurt a.M. 2005: 47-59.

Schrader-Breymann H. Der Kindergarten als Vorbereitung für das Leben. In: Kleine Pädagogische Texte. Henriette Schrader Breymann, eds. E. Blochmann, G. Geißler, H. Nohl, E. Weniger. Julius Beltz. Weinheim 1962: 112-122.

Schwarz R. Frühe Bewegungserziehung. Ernst Reinhardt. München 2014a.

SchwarzR. EffektederBewegungsförderung-ReviewlängsschnittlicherEvaluationsstudienzufrühkindlichen Bewegungsinterventionen. Motorik. 2014b; 37 (2): 52-63.

Schwarz R. Bewegung \& Bildung in der frühen Kindheit - Qualitätseffekte von Bewegungskindergärten im empirischen Vergleich (BeBi-Studie): Hofmann, Schorndorf 2015 (in press).

Stiehl F. Die drei Preußischen Regulative vom 1., 2. und 3. October 1854 über Errichtung des evangelischen Seminar-, Präparandenund Elementarschul-Unterrichts (6nd ed). Wilhelm Hertz. Berlin 1858.

Tietze W., Förster Ch. Allgemeines pädagogisches Gütesiegel für Kindertageseinrichtungen. In: Der Streit ums Gütesiegel. Qualitätskonzepte für Kindertageseinrichtungen, eds. A. Diller, H.R. Leu, Th. Rauschenbach. Verlag Deutsches Jugendinstitut. München 2005: 31-66.

Tietze W., Viernickel S. Pädagogische Qualität in Tageseinrichtungen für Kinder. Ein nationaler Kriterienkatalog. Cornelsen Scriptor. Berlin 2007.

Tietze W. Wie gut sind unsere Kindergärten? Eine Untersuchung zur pädagogischen Qualität in deutschen Kindergärten. Luchterhand. Neuwied 1998.

Tietze W., Roßbach H.-G., Grenner K. Kinder von 4 bis 8 Jahren. Zur Qualität der Erziehung und Bildung in Kindergarten, Grundschule und Familie. Beltz. Weinheim 2005.

Vorländer H. Die NSV. Darstellung und Dokumentation einer nationalsozialistischen Organisation. Harald Boldt Verlag. Boppard am Rhein 1988.

Zimmer R. Handbuch der Bewegungserziehung. Didaktisch-methodische Grundlagen und Ideen für die Praxis. Herder. Freiburg i.Br. 1993.

Zimmer R. Alles über den Bewegungskindergarten. Herder. Freiburg i.Br. 2006.

Cite this anticle aS: Schwarz R. From Past till Presence - The Quality of German Physical Activity Kindergarten (PAK). Central European Journal of Sport Sciences and Medicine. 2015; 11 (3): 103-113. 
